Portland State University

PDXScholar

$1-2013$

\title{
Economic Development and Gender Equality: Is \\ There a Gender Kuznets Curve?
}

Joshua Eastin

Portland State University

Aseem Prakash

University of Washington - Seattle Campus

Follow this and additional works at: https://pdxscholar.library.pdx.edu/polisci_fac

Part of the Growth and Development Commons, Political Economy Commons, and the Political Science Commons

Let us know how access to this document benefits you.

\section{Citation Details}

Eastin, J., \& Prakash, A. (2013). Economic Development and Gender Equality: Is There a Gender Kuznets Curve?. World Politics, 65(1), 156-186. doi:10.1017/S0043887112000275

This Article is brought to you for free and open access. It has been accepted for inclusion in Political Science Faculty Publications and Presentations by an authorized administrator of PDXScholar. Please contact us if we can make this document more accessible: pdxscholar@pdx.edu. 


\title{
Research Note \\ ECONOMIC DEVELOPMENT AND \\ GENDER EQUALITY \\ Is There a Gender Kuznets Curve?
}

\author{
By JOSHUA EASTIN and ASEEM PRAKASH*
}

\section{INTRODUCTION}

U NDER what conditions does economic development improve gender equality? We argue that the effects of economic development on gender equality are contingent on the particular developmental phase. Drawing on Simon Kuznets's thesis regarding a curvilinear relationship between economic growth and income inequality, we suggest that economic development and gender inequality also exhibit a nonmonotonic relationship, marked by three phases. ${ }^{1}$ In the first phase, economic development should improve gender equality; in the second phase, equality should plateau or even decline slightly; and in the third phase, it should rise again. Our thesis has important policy implications because scholars and practitioners tend to assume that development alone will improve gender equality. The evidence we present suggests that in each developmental phase, particularly in the second phase, measures to respond to gender issues should accompany policies to promote economic development.

Our article builds on an extensive world politics literature on the consequences of economic development for women's status. ${ }^{2}$ Critical and feminist scholars suggest that contemporary development strate-

\footnotetext{
* A previous version of this article was presented at the 2009 annual conference of the International Studies Association. We thank Susan Sell, Rebecca Szper, and Mike Ward for comments. Brad Epperly and Kristan Seibel provided invaluable technical assistance. Joshua Eastin acknowledges financial support from the Harry Bridges Center for Labor Studies, University of Washington. Aseem Prakash acknowledges financial support from the Center for International Business Education and Research, University of Washington.

${ }^{1}$ Kuznets 1955. 2010.

${ }^{2}$ Weiss, Ramirez, and Tracy 1976; Clark et al. 1991; Dollar and Gatti 1999; Kanbur and Spence
} 
gies can strengthen patriarchal institutions, expose women to exploitative production practices, and force them into low-paying jobs - all of which undermine gender equality. ${ }^{3}$ In contrast, neoliberals (or growth optimists) suggest that economic development should enhance women's status because it encourages societal integration, supports women's investment in human capital, and creates employment opportunities for women in relatively higher paying nonfarm sectors. ${ }^{4}$ Similarly, as growth drivers, international trade and foreign direct investment diffuse productivity-enhancing (and labor-saving) technologies and encourage norms of gender equity. ${ }^{5}$ Consequently, this thinking goes, economic development should have a positive impact on gender equality. ${ }^{6}$

A third perspective, introduced by Boserup and developed by scholars such as Goldin and Iversen and Rosenbluth, recognizes that while in the early phases of development both macropatriarchal and micropatriarchal institutions might limit women's occupational opportunities, sustained growth should enhance female labor-force participation. ${ }^{7}$ Outside employment provides women with an independent revenue stream, facilitates human capital development, and strengthens their domestic bargaining power, which in turn should undermine patriarchal social structures. Consequently, the relationship between economic development and gender equality is likely to follow a U-shaped pattern: equality decreases in the initial stages of development and then increases beyond some economic threshold. This is an important finding because it challenges the existing literature, which tends to view development as either "good" or "bad" for gender equality across the developmental spectrum.

We demonstrate that the relationship between development and gender equality is even more complex-a finding with important policy implications. Rather than an inverted $U$ with two stages, we suggest that development's effects on gender equality should resemble an $\mathrm{S}$ shape, proceeding in three stages: first increasing equality, then decreasing or decelerating equality, and finally increasing again. These findings raise important theoretical and policy issues pertaining to the consequences of economic development on gender issues. The policy implication of the U-shaped model suggests that once an economic threshold is crossed, development should encourage progress on gender

\footnotetext{
${ }^{3}$ Tinker 1976.

${ }^{4}$ Weiss, Ramierez, and Tracy 1976; Clark 1991; Clark, Ramsey, and Adler 1991; Forsythe, Korzeniewicz, and Durrant 2000.

${ }^{5}$ Neumayer and DeSosya 2007.

${ }^{6}$ Richards and Gelleny 2007; Gray, Kittilson, and Sandholtz 2006.

${ }^{7}$ Boserup 1970; Goldin 1990; Iversen and Rosenbluth 2006.
} 
issues. In our perspective, the two-stage model overlooks the first stage where economic development encourages equality gains. We believe that this initial progress might lull policymakers and activists into believing that gender equality will only improve in the future (or that society is in the second stage of the U-shaped curve). Indeed, our findings illustrate the dangers of the middle phase, where gender gains can level off or even decline, and call for vigorous policy actions to serve as correctives. Thus, the policy and political implications of the S-shaped perspective substantially differ from those of the U-shaped perspective.

Following Grossman and Krueger, we employ a cubic specification of per capita income, a primary indicator of economic development and the key variable of interest. ${ }^{8}$ Our analyses of a panel of 146 developing countries for the period 1980-2005 suggest a curvilinear relationship between economic development and gender equality, or the presence of a gender Kuznets curve (GKC). We estimate the two thresholds- the transition from the first to the second stage and from the second to the third stage - to be approximately $\$ 8,000-10,000$ and $\$ 25,000-30,000$ per capita, respectively.

What mechanisms might explain the GKC? To what extent are the transitions between stages endogenous to the growth process? Following Goldin and Iversen and Rosenbluth, we suggest that political, economic, and social opportunities associated with different developmental stages, and the changes in household-level and macrosocial institutions they unleash, create a push for gender equality (and then a pushback in the second stage). In particular, labor-force participation affords women an independent income stream and improves their intrafamily bargaining power. Increased human capital and higher social visibility accumulated in occupational pursuits aid this progression. However, these processes are refracted through patriarchal institutions and reactionary forces, which seek to perpetuate the status quo and reinforce patriarchal dominance. Thus, economic, social, and political advancement at different developmental stages reflects the tension between social normative evolution and economic imperatives on the one hand and the resistance generated by the structures of patriarchal systems on the other. Consequently, opportunities for gender advancement do not necessarily always increase or decrease as economies develop.

Goldin finds that higher levels of female labor-force employment tend to exist at lower income levels when agriculture dominates. ${ }^{9}$

\footnotetext{
${ }^{8}$ Grossman and Krueger extended Kuznets's work to suggest a curvilinear relationship between growth and environmental degradation, the so-called environmental Kuznets curve. See Grossman and Krueger 1995. See also Zeng and Eastin 2011.

${ }^{9}$ Goldin 1995.
} 
As incomes rise and manufacturing sectors gain prominence, limited educational opportunities and stigmatizing social customs depress female labor-force participation. However, as the service sector gains prominence and new educational opportunities facilitate white-collar employment, the opportunity cost of staying at home as opposed to joining the labor force increases. Consequently, the stigma of joining the workforce diminishes and gender equality improves. In short, the declining portion of the U-shaped curve illustrates the dominance of the income effect (changes in women's work hours in response to changes in family income, ceteris paribus) over the substitution effect (changes in women's work hours in response to changes in her wage rates, ceteris paribus), while the rising portion illustrates the opposite.

Our work both supports and supplements Goldin's findings. Like Goldin, we suggest that in the initial stages of economic development (below \$8,000-10,000), women experience relatively greater employment opportunity gains when compared with the second developmental stage. Political and social spheres eventually reflect gains achieved in the labor force. Indeed, we find that political equality (female parliamentary participation), economic equality (female labor-force participation), and a combination of political, social, and economic equality (Gender Development Index and Gender Equality Measure) exhibit a nonmonotonic $\mathrm{S}$-shaped relationship with economic development.

To elaborate on the mechanisms, in the initial stage of economic development, labor-force participation enhances female domestic bargaining power and affords women greater social and economic visibility. ${ }^{10}$ However, extant patriarchal institutions attempt to limit this advancement. In some cases, there is a backlash as these reactionary forces gain traction in their efforts to roll back initial empowerment gains. Scholarly work supports this proposition. Steel and Kabashima attribute the high levels of gender inequality evident in East Asia to historical political-institutional carryovers that incorporated gender inequality in the state-sponsored modernization processes. ${ }^{11}$ In contemporary India the parliamentary bill to enact quotas for women in the national and state legislatures has caused major political gridlock.

Perverse social norms may take on new life with economic prosperity. Drawing on National Sample Survey data from India, Das and Desai report that cultural factors influence women's labor-force withdrawal. They find that as a family's status improves, social norms that discourage 2006.

${ }^{10}$ On how societal institutions influence intrahousehold dynamics, see Iversen and Rosenbluth

${ }^{11}$ Steel and Kabashima 2008. 
female labor-force participation gain traction because female employment can threaten family honor. ${ }^{12}$ In another study, Hvistendahl reports that female fetal abortions tend to follow female empowerment in many Asian countries, because male children confer higher social status. ${ }^{13}$ In other words, social norms that favor male children condition female decisions to abort. ${ }^{14}$ Such biases are common among the richer and more educated Indian classes. According to the 2011 Indian census, unfavorable sex ratios predominate in the more affluent areas such as Delhi (866 women per 1,000 men), Punjab (893 per 1,000), and Haryana $(877$ per 1,000$)$. Research based on a large sample (over $100,000)$ of rural and urban households suggests this trend persists across provinces/states. ${ }^{15}$ To summarize, a perverse pushback effect can cause a plateau in gender equality or even reduce it in the second development phase. We estimate these effects to be at their most prominent in the range of per capita income levels between $\$ 8,000$ and $\$ 10,000$.

Further increases in economic development, however, can impart new momentum to gender norms and social institutions that enable women to build on previous advancements. In the third developmental phase (beyond $\$ 25,000-30,000$ ), education and human capital development and the concomitant high opportunity costs of female labor-force abstinence encourage greater labor-force participation and greater acceptance of women in positions of authority. This push toward greater gender equality tends to overcome status quo opposition, which also begins to weaken as norms of gender equality become more institutionalized. Although reactionary forces do not disappear, they lose support as structural changes in the economy create conditions favoring gender equality.

While the GKC hypothesis potentially explains the varying and contradictory relationship between development and gender equality, we want to clarify an important issue before we proceed. The two inflexion points we report in this study are not magic thresholds that miraculously create new social relationships and lead to dramatic changes in women's status. The reported income thresholds are econometric estimations based on data from a panel of 146 countries for the period

${ }^{12}$ Das and Desai 1993. A similar finding is reported in a recent paper by Eswaran, Ramaswamy, and Wadhwa 2009. At http://econ.arts.ubc.ca/meswaran/status.pdf.

${ }_{13}^{13}$ Hvistendahl 2011.

${ }^{14}$ In the context of Middle East, Blaydes and Linzer 2008, 577, observe: "Nevertheless, many Muslim women support and identify with the fundamentalist Islamic social and political movements that promote these practices and beliefs and, indeed, often willingly participate in these practices themselves."

${ }^{15}$ Siddhanta, Nandy, and Satish B 2005. These issues have been taken up in the popular press as well. See, for example, Douthat 2011; and Economist 2011. 
1980-2005. With new technologies, norms, and policy interventions, these inflexion points can shift, and the deleterious second phase can shrink. Human agency can, and often does, aid this process. For example, a social movement that explicitly seeks to empower women can reverse trends that might erode women's rights. Such movements might have greater opportunities to flourish in a digital society, as the "car driving protest" in Saudi Arabia suggests. Our story is really about economic processes interacting with social institutions, a contest between progressive and reactionary forces across developmental stages. Different stages encourage varying levels of gender equality via female labor-force participation. As economic and normative pressures for equality accumulate, at some "tipping point"16 (the estimated income thresholds) we expect new norms, institutions, and power relations to emerge and manifest themselves in changes to women's status. Our article should, therefore, be viewed as a call for concerted policy and social action to shorten the span of the second developmental stage, which is inimical to women's rights. Development scholars and practitioners should anticipate that patriarchal institutions might seek to reverse gains in gender equality and prepare for concerted social and policy action in anticipation of such pushback.

\section{Economic Development and Gender EQuality: TheOrETICAL EXPECTATIONS}

Scholars have engaged in extensive debate about the link between economic development and women's social, economic, and political status. Critical, and some feminist, scholars emphasize that micro- and macro-social institutions limit women's capacity to attain equal status. They claim that capitalist modes of development strengthen such institutions, which persist in spite of economic development. ${ }^{17}$ The implication is that to change the status of women, there needs to be a direct intervention - or social engineering - rather than relying solely on economic development to do the job. ${ }^{18}$

Two strands prevail in this school of thought. ${ }^{19}$ The first suggests that development alone does not improve female labor-force participation or undermine occupational stratification and discriminatory cultural and legal institutions. Studies cite examples of female labor-force withdrawal as economic development increases male earnings. This

\footnotetext{
${ }^{16}$ Cao, Greenhill, and Prakash forthcoming.

${ }^{17}$ Jütting et al. 2006.

${ }_{18}$ Beneria and Sen 1982.

${ }^{19}$ For a more extensive treatment, see Forsythe, Korzeniewicz, and Durrant 2000.
} 
process obligates women to exit the formal labor markets and tend to household duties. ${ }^{20}$ When women do enter the workforce, they are restricted to menial and low-level clerical positions that reflect institutionalized gender biases. ${ }^{21}$

Scholars also consider how discriminatory legal institutions and cultural traditions can limit women's ability to achieve equal status. ${ }^{22}$ Youssef identifies marital and fertility characteristics intrinsic to certain Middle Eastern cultures as highly inimical to gender equality. ${ }^{23} \mathrm{~A}$ report by the United Nations Development Program identifies a slew of institutionalized and cultural practices that lead to gender discrimination. ${ }^{24}$ These include laws that fail to sanction violence against women, discriminatory labor laws, restrictive property laws, and subordinate fertility laws. ${ }^{25}$ Similarly, certain fundamentalist belief systems discourage female employment, which diminishes intrahousehold bargaining power. Women themselves sometimes support these same discriminatory beliefs because holding such views can increase a woman's "value" in the "marriage market." 26

The second strand of the critical school suggests that certain types of economic development erode gender equality. ${ }^{27}$ Dependency scholars note that the recruitment of males into the formal labor force leads to male out-migration to urban areas. This process denies women opportunities for upward social mobility and formal employment, because it forces them to remain at home and focus on agricultural and reproductive pursuits. If formal labor-force participation is possible, labor discrimination and female confinement to menial and subordinate positions reinforces preexisting notions and practices of inequality. These discriminatory practices can be cultural, as mentioned above, but they can also arise from gender specialization in the division of labor. For example, economies dependent on export agricultural production can be more accepting of patriarchal norms that favor men over women. ${ }^{28}$

In contrast to the critical school, the "optimists," informed primarily by neoclassical economic theory, expect labor-force inequali-

${ }^{20}$ Wilensky 1968.

${ }^{21}$ Oppenheimer 1970; Blackburn and Jarman 2006. Indeed, the European Parliament is contemplating legislation that mandates a 40 percent quota for women on company boards to resolve their poor representation, which stands currently at about 9.7 percent. See http://euobserver.com/18/32598.

${ }_{22}$ Youssef 1972; Folbre 1986.

${ }^{23}$ Youssef 1972. For a different perspective, see Ross 2008.

${ }^{24}$ United Nations Human Development Report 1995.

${ }^{25}$ United Nation Human Development Report 1995.

${ }^{26}$ Blaydes and Linzer 2008.

${ }^{27}$ Tinker and Bramsen 1976; Ward 1984.

${ }^{28}$ Iversen and Rosenbluth 2005. 
ties to decline with economic growth because discriminatory policies are costly to maintain. In some cases, favoring men over women can impose unnecessary costs on employers. ${ }^{29}$ Labor-saving technologies allow women to devote less time to domestic and agricultural duties, thereby enabling them to seek outside employment or focus on skill acquisition. ${ }^{30}$ Households find it increasingly worthwhile to educate girls to turn them into income-generating assets. ${ }^{31}$ These dynamics should lead to higher levels of female empowerment within the family as women contribute a rising share of family income. ${ }^{32}$ Similarly, Inglehart argues that the postmaterialist values that develop concomitantly with expanded educational opportunities and increased literacy rates encourage the adoption of social norms that discourage gender discrimination. ${ }^{33}$

Boserup was among the first to articulate the possibility of a nonlinear relationship between growth and gender equality. ${ }^{34}$ She recognized that some stages of industrialization correlate with declining gender equality as male out-migration forces women to focus on domestic chores. However, as growth proceeds and households become less dependent on subsistence farming, women gain opportunities to pursue external employment. From the demand side, industrialization and growth increase macrolevel demand for labor. As birth rates decline and female human capital development increases through education, job training, and formal labor-force participation, women achieve greater monetary leverage within the domestic family structure. Over time, this process should encourage the adoption of social norms that discourage gender discrimination, and these, in turn, should enable greater political recognition, participation, and social equality.

Empirical studies testing Boserup's thesis have produced mixed results and tend to suffer from limited comparative data. ${ }^{35}$ Forsythe et al. find support for the GKC in some regions and levels of income and support for a positive linear relationship (between development and gender equality) among others. ${ }^{36}$ To the best of our knowledge, our study is the first to systematically test the GKC hypothesis for a panel of a large number of countries (146) over an extended time period (1980-2005),

\footnotetext{
${ }^{29}$ Sarasúa 2008.

${ }^{30}$ Weiss, Ramirez, and Tracy 1976; Clark, Ramsby, and Adler 1991; Inkles and Smith 1974.

${ }^{31}$ Becker 1985; Mincer 1958.

32 Seguino 2007.

${ }^{33}$ Inglehart 1977; Inglehart 1997.

${ }^{34}$ Boserup 1970.

${ }^{35}$ Boserup 1970; Lantican, Gladwin, and Seale 1996; Forsythe, Korzeniewicz, and Durrant 2000.

${ }^{36}$ Forsythe, Korzeniewicz, and Durrant 2000.
} 
using multiple indicators to capture social, political, and economic dimensions of gender equality. Our results reveal a consistent curvilinear relationship between our indicators and economic development.

Theoretically, we suggest that GKC is a useful and powerful way to think about the relationship between development and gender equality. Kuznets postulated the curvilinear relationship between economic development and income equality. ${ }^{37}$ Since that time, scholars have extended the Kuznets curve idea to other areas-environmental pollution, for example. ${ }^{38}$ The core insight in the different Kuznets curve literatures is that the effect of economic development on the variable under study is contingent on the level of development. Consistent with Grossman and Krueger, we hypothesize that development and gender equality should exhibit an S-shaped, nonmonotonic pattern: first increasing as economic development confers improvements in economic, social, and political rights, then plateauing or declining as discriminatory institutions limit women's developmental opportunities. ${ }^{39}$ Finally, as income increases beyond a certain threshold, it leads to the evolution of new norms and institutions that support gender equality. This process becomes self-reinforcing as women develop the human capital necessary for continued advancement in the labor force.

Economic and social institutions at both the microlevel (household) and the macrolevel (society) play an important role in our theoretical story. In the first stage, technological progress and declining birth rates increase female employment opportunities in both the formal and the informal sectors. ${ }^{40}$ These factors also increase the opportunity costs of remaining outside the labor force, making staying at home relatively more costly. At the household level, external employment gains enable women to increase their share of family income and therefore their bargaining power within the family. ${ }^{41}$ Households are willing to invest in educating their daughters because increased income reduces dependence on female labor for household chores and because increased revenue offsets educational costs. At the societal level, promotional opportunities and human capital developed in the workforce empower women and confer new political, social, and economic rights. Deere documents the implications of women's employment in nontraditional agricultural export sectors across Latin America. ${ }^{42}$ She notes:

\footnotetext{
${ }^{37}$ Kuznets 1955.

${ }^{38}$ Grossman and Krueger 1995; Cao and Prakash 2010.

${ }^{39}$ Grossman and Krueger 1995.

${ }^{40}$ Mummert 1994; Goldin 1995.

${ }^{41}$ Iversen and Rosenbluth 2006.

${ }^{42}$ Deere 2005.
} 
"[T]he main way that wage work has contributed to women's potential empowerment is through the greater bargaining power that their household monetary contributions garner them." ${ }^{43}$ Similarly, Mummert found that employment opportunities in the Mexican strawberry industry have enabled women to develop a greater freedom of mobility, as well as an increased decision-making capacity within the home on issues such as childbearing, marriage, and occupational involvement. ${ }^{44}$ Such employment opportunities reinforce the gains made in this area as women begin to assume greater occupational leadership roles as supervisors and/or union organizers.

In effect, social rights and norms that encourage gender equality evolve in the household as women gain access to independent revenue streams and in society as women develop human capital and acquire positions of occupational power. These processes increase political participation and representation, and expand social networks. Thus, the first stage of economic growth facilitates a relative improvement in gender equality.

Advances in gender equality in the initial stages of economic development, however, do not continue indefinitely. Social and cultural institutions endogenous to economic development processes play an important role in limiting gains in the second stage. While development in the first stage increases the opportunity costs of women abstaining from formal employment, gains in female income should not be expected to correlate with those of men because sexual stratification and discrimination in the labor force limit women's advancement. In the household, diverging male/female income trajectories decrease the relative opportunity costs of women remaining home and lend traction to preexisting social norms that stigmatize men whose wives are employed. ${ }^{45}$ An empirical study documents the above dynamics in the context of women's economic and social dependency in Nizhnii Novgorod, Russia. The author finds that although entry into the formal labor force enhances women's personal freedoms, it also reinforces preexisting gender inequalities. ${ }^{46}$ Another study finds that economic development has both positive and negative impacts on female employment in Sri Lankan export processing zones, because while increased income generates greater economic capacity and female bargaining power, it simultaneously supports gendered subordination. ${ }^{47} \mathrm{In}$

\footnotetext{
${ }^{43}$ Deere 2005, 54

${ }^{44}$ Mummert 1994.

45 Goldin 1990.

${ }^{46}$ Balabanova 2007.

${ }^{47}$ Hancock 2006.
} 
this context, growth is a double-edged sword, initially creating opportunities but then also limiting them.

This process plays out in broader social spheres as increased female bargaining power threatens extant patriarchal institutions, which in turn push back against equality gains achieved in the initial phase of development. Declining opportunity costs of female labor-force abstinence lend traction to arguments made by status quo beneficiaries, and calls to return to "traditional values" come to dominate the social discourse. Scholars have observed this phenomenon in the Middle East, noting: "With respect to gender norms, newly urbanized populations found it difficult to accept the changing role of women that accompanied modernization, particularly as women began to work in nontraditional areas." ${ }^{48}$ Arguably, this pushback might also result from increased competition as newly trained and educated women compete with men for scarce job openings.

Ultimately, however, continued economic development should again encourage gains in gender equality. While the second stage of development encourages female workforce retrenchment, which limits gender advancement, this process should not necessarily lead to declining female educational participation. Daughters continue to attend school, which increases their human capital and heightens the future value of their participation in the workforce. Over time investments in education and human capital development again increase the opportunity costs of female labor-force abstinence, and arguments that support patriarchal dominance lose ground to the possibility of greater gains in family income. At the societal level, increased economic clout, social visibility, and human capital development encourage new social institutions and norms that supplant prior structures of cultural, social, and legal discrimination. This process advances women's political rights, as women gain a footing in the political domain and adopt leadership roles at work and at home. This stage could signify the beginning of the "postmaterialist values" in a gendered context that "de-emphasize(s) the instrumental rationality that characterize(s) industrial society." ${ }^{\prime 9}$ In this phase, economic development both diminishes the institutional desirability of gender discrimination and facilitates a shift in social value systems toward gender equality.

\footnotetext{
${ }^{48}$ Blaydes and Linzer 2008, 579.

${ }^{49}$ Inglehart 1997, 5.
} 


\section{DATA AND VARIABLES}

To test the GKC hypothesis, we have compiled a cross-sectional, timeseries data set covering 146 developing countries for the period 19802005. ${ }^{50}$ To the best of our knowledge, this research note provides one of the most comprehensive assessments of the impact of economic development on alternative measures of gender inequality in developing countries. To deal with the issue of missing data, we employ a multiple imputation procedure using the "Amelia" package in R specifying both time and country fixed effects for each imputed variable. This procedure allows patterns in each variable to vary over time and among each cross-sectional unit, which should result in a more robust imputation. In the imputation procedure, we employ a range of variables highly correlated to our independent and dependent variables of interest that we do not include in our models to further increase the imputed data's robustness. We place a lower bound of zero on per capita GDP to avoid estimating models with significant and unrealistic outliers. We run models on both imputed and nonimputed data with no significant differences in key results, leading us to conclude that the imputations successfully predict the missing observations.

\section{DEPENDENT VARIABLES}

Our dependent variable captures different dimensions of gender equality. ${ }^{51}$ We adopt the United Nations definition of gender equality: “... that [women's and men's] rights, responsibilities and opportunities will not depend on whether they are born male or female." ${ }^{52}$ We employ four dependent variables to capture economic, social, and political dimensions of gender equality. These are:

1. the United Nations Gender-related Development Index,

2. the United Nations Gender Equality Measure ${ }^{53}$

The above indices present a composite assessment of gender equality along social, economic, and political dimensions. Because economic growth may affect these dimensions in different ways, we test our hy-

\footnotetext{
${ }^{50}$ We employ the International Monetary Fund's classification, including both "emerging" and "developing" economies in the sample: IMF Emerging and Developing Economies List. World Economic Outlook Database 2008.

${ }^{51}$ Sudarkasa 1986; Richards and Gelleny 2007.

${ }^{52}$ Human Development Program. Gender Definitions. At http://www.spc.int/hdp/index.php? option=com_content\&task=view\&id=31\&Itemid=53, accessed December 12, 2011.

${ }^{53}$ For detailed descriptions of the GDI and GEM, see United Nations: Gender-related Development Index and Gender Equality Measure. At http://hdr.undp.org/en/statistics/indices/gdi_gem/, accessed June 2, 2008.
} 
pothesis on two individual indicators of these dimensions from the World Bank's World Development Indicators data set:

3. economic and social equality: female labor-force participation,

4. political equality: female parliamentary participation

To elaborate, the Gender-related Development Index (GDI) is a gendered alternative to the well-known Human Development Index (HDI). The GDI employs standardized data culled from national sources. As a composite index, the GDI gauges the relative (to men) status of women in three areas: health and longevity (the ratio of women's to men's life expectancies at birth), knowledge (female/male ratios for adult literacy rate and primary, secondary, and tertiary enrollment), and standard of living (female/male ratio of per capita gross domestic product). Higher GDI scores reflect higher levels of gender equality. The methodology used to construct the GDI imposes a penalty for countries when the overall achievement level of both women and men falls and/or when the relative disparity between women and men increases.

While the GDI gauges relative status of women according to basic structural characteristics, the Gender Empowerment Measure (GEM) evaluates the extent to which women and men can equitably participate in political and economic life and in decision-making processes. The UN notes: "While the GDI focuses on expansion of capabilities, the GEM is concerned with the use of those capabilities to take advantage of the opportunities of life. ${ }^{" 54}$ Further, the "GEM is more ambitious as it aims to measure women's empowerment on a global scale ... built on ... indicators measur[ing] the female share of political power (seats in parliament), managerial positions in the administrative and professional sectors... [and] income. ${ }^{55}$ The GEM measures inequality on three dimensions, economic participation and decision-making power (the share of females occupying professional and technical positions, positions in the legislature, senior officials, and managers), political participation and decision making (share of female parliamentary seats), and power over economic resources (ratio of female to male estimated earned income). ${ }^{56}$

Our two remaining variables approximate a key dimension of gender equality and women's status. Female Parliamentary Participation measures the percentage of women in a country's primary legislative body.

\footnotetext{
${ }^{54}$ United Nations: Gender-related Development Index and Gender Equality Measure. At http:// hdr.undp.org/en/statistics/indices/gdi_gem/, accessed June 2, 2008.

${ }_{55}$ Charmes and Wieringa 2003, 419.

${ }^{56}$ United Nations: Gender-Related Development Index and Gender Equality Measure. At http:// hdr.undp.org/en/statistics/indices/gdi_gem/, accessed June 2, 2008.
} 
Parliamentary participation is a key indicator of the extent to which women occupy positions of political power in a country, which can approximate gender equality in the political sphere. Labor Force Participation reflects the percentage of women in a country that participate in the formal labor force. Though labor-force participation underreports women's contribution to overall production efforts, it is the key vehicle for economic empowerment for two reasons: first, because participation affords women an independent income stream, which improves their intrahousehold bargaining power; and second, because it allows women to accumulate human capital, which lends them greater social and economic visibility.

\section{Key Independent Variable}

Our key independent variable is economic development measured in terms of GDP per capita in constant US dollars (2000). We also estimate models by employing GDP per capita adjusted for purchasing power parity and find that the substantive results did not change. To test for a curvilinear relationship between development and equality, consistent with the environmental Kuznets curve literature, our models include quadratic and cubic specifications of per capita GDP. ${ }^{57}$

\section{Control Variables}

To account for alternative mechanisms that might affect gender equality, our models include a slate of control variables. We control for political and social factors that can independently affect gender equality. We control for democracy because it is often assumed that democratic regimes have greater respect for human rights, including women's rights, relative to authoritarian regimes. We draw data from the Polity IV Project: Political Regime Characteristics and Transitions, 1800-2002 data set. ${ }^{58}$ These data are ordinal and range from -10 (strongly autocratic) to +10 (strongly democratic). Next we control for conflict. Gender equality suffers in conflict situations through direct victimization of women and indirect spousal and child loss. ${ }^{59}$ Prolonged periods of conflict can also limit a society's capacity to cultivate and develop social norms and invest in social programs that promote gender equality. ${ }^{60}$ We control for a country's involvement in international or domestic conflict by including a dichotomous variable coded 1 if a country was a participant in a conflict and 0 if not. The data are from the Uppsala

\footnotetext{
${ }^{57}$ For information on the environmental Kuznets curve, see Grossman and Krueger 1995.

${ }^{58}$ Marshall and Jaggers 2005.

${ }^{59}$ Gangoli 2006.

${ }^{60}$ Jansen 2006.
} 
Conflict Data Program and International Peace Research Institute (UCDPPRIO). ${ }^{61}$ This data set defines conflict as "a contested incompatibility that concerns government and/or territory where the use of armed force between two parties, of which at least one is the government of a state, results in at least 25 battle-related deaths." ${ }^{2}$

Our models control for economic factors that may influence gender equality. Recent empirical work finds that globalization can improve gender equality because trade and foreign direct investment (FDI) generate employment opportunities for women. ${ }^{63}$ Other scholars contend that policies designed to increase trade and FDI inflows reduce state revenue and therefore diminish the state's capacity for social service provision. ${ }^{64}$ Because women are often the key beneficiaries of these services, economic integration can undermine gender equality. Furthermore, economic integration can solidify gendered occupational segregation, which forces women into poorly paid jobs. ${ }^{65}$ We control for level of exports (as a percentage of GDP) and FDI (Inward FDI stock/GDP) without assuming a prior position on their directionality. We employ trade data from the World Bank's WDI Dataset and FDI data from the United Nation's Foreign Direct Investment Database. ${ }^{66}$

We control for a country's participation in structural adjustment policy (SAP) imposed by the International Monetary Fund and the World Bank. These policies require governments to balance budgets, usually by cutting expenditures. Budget cuts often reduce social service provision and public sector employment. Because women tend to benefit disproportionately from these services, SAPs can have profound consequences for gender equality. ${ }^{67} \mathrm{We}$ control for a country's SAP participation in a given year by including a dichotomous variable, coded 1 if the country operated under an SAP and 0 if not. ${ }^{68}$

Our models control for the industrial composition (industry) of the economy as reflected in the share of manufacturing sector in the GDP. This is because a higher salience of the manufacturing sector could be associated with higher levels of formal female labor-force participation. Finally, we include economic growth to control for the possibility

${ }^{61}$ Gleditsch et al. 2002.

${ }^{62}$ Harbom 2007, 4.

${ }^{63}$ Apodaca 2001; Richards, Gelleny, and Sacko 2001; Richards and Gelleny 2007; Gray, Kittilson, and Sandholtz 2006.

${ }^{64}$ Hemmati 2001; Rao, Aruna, and Kelleher 2005.

${ }^{65}$ United Nations Development Program 1999.

${ }^{66}$ United Nations Conference on Trade and Development: Foreign Direct Investment Database. Accessed June 18, 2008.

${ }^{67}$ Bergeron 2001; Acker 2004.

${ }^{68}$ Abouharb and Cingranelli 2006. 
TABLE 1

Descriptive Statistics

\begin{tabular}{lcrrrrrrr}
\hline \hline & GDP & \multicolumn{1}{c}{ SAP } & Democracy & Conflict & Exports & \multicolumn{1}{c}{ FDI } & Industry & Growth \\
\hline Mean & \multicolumn{1}{c}{2.4} & 0.48 & 0.42 & 0.18 & 36.08 & 28.99 & 30.64 & 3.43 \\
Median & 1.19 & 0 & 0.70 & 0 & 31.92 & 14.41 & 28.73 & 3.92 \\
SD & 3.76 & 0.5 & 6.56 & 0.39 & 21.26 & 80.88 & 13.43 & 7.46 \\
Min & 0.04 & 0 & -10 & 0 & 1.1 & -130.16 & 0.79 & -51.03 \\
Max & 45.39 & 1 & 10 & 1 & 131.13 & 2036.99 & 94.21 & 151.83 \\
1st Q. & 0.42 & 0 & -7 & 0 & 19.58 & 5.29 & 21.08 & 0.95 \\
3rd Q. & 2.87 & 1 & 7 & 0 & 49.07 & 33.09 & 38.31 & 6.33 \\
\hline
\end{tabular}

\begin{tabular}{lcccc} 
& GDI & GEM & Labor & Parliament \\
\hline Mean & 0.60 & 0.38 & 38.36 & 9.67 \\
Median & 0.63 & 0.39 & 40.13 & 8.66 \\
SD & 0.17 & 0.11 & 9.22 & 6.81 \\
Min & 0.11 & 0.04 & 5.05 & 0 \\
Max & 0.98 & 0.78 & 55.71 & 48.80 \\
1st Q. & 0.47 & 0.30 & 33.21 & 4.32 \\
3rd Q. & 0.73 & 0.46 & 45.62 & 13.20 \\
\hline
\end{tabular}

that an economic slowdown or decline might have adverse effects on gender equality independent of the level of development. We take data for industry and economic growth from the World Bank's WDI Dataset. (See Table 1.)

\section{Model, Analysis, And Results}

We estimate the effects of economic development on four dependent variables that capture a diverse picture of gender equality and women's status. Each variable represents a different facet of political, social, and economic gender equality. We employ linear mixed-effects models (with polynomials) with country random effects. We run all models with both per capita income and per capita income adjusted for purchasing power parity, our key independent variables. The results were substantively the same, which is not surprising, given that these variables are highly correlated (0.87). All dependent variables (GDI, GEM, Labor-Force Participation, and Female Parliamentary Participation) can be viewed as continuous. However, because these variables are bound by 1 and 0 , we also run models using logit-transformed dependent variables. These results are substantively the same, with no major differences in the significance of the variables of interest across all models. We report the results from nontransformed variables to facilitate substantive 
interpretation. ${ }^{69}$ Durbin-Watson test statistics do not indicate a significant danger of autocorrelation in any of the models, and correlation statistics do not indicate that multicollinearity is a danger. Finally, we run all models with independent variables with one-, three-, and fiveyear lags to mitigate endogeneity concerns. ${ }^{70}$ Because none of these models significantly affected our key results, we report the models with no lags to avoid diminished sample sizes.

Figure 1 displays the relationship between development and various dimensions of gender equality. We constructed these graphs using the coefficients obtained in the regression equations. The $\mathrm{X}$-axis represents per capita income (in thousands of dollars), and the Y-axis, the gender equality variables. These graphs enable assessment of effects of development on gender equality at each developmental stage. We structure the dependent variables on the $\mathrm{Y}$-axis such that increases, or movements up the axis, represent equality gains. The inflexion points (marking different phases in the evolution of gender rights) for the hypothesized curvilinear relationships are around $\$ 8,000-\$ 10,000$ and $\$ 25,000-\$ 30,000$.

Table 2 presents the results of our statistical analyses. We find evidence that per capita income (including its squared and cubed forms) is a significant predictor of gender equality across models. F-tests comparing models that include the quadratic and cubic terms with those that include only the linear term indicate that the full models provide a better fit. The directionality of these variables corresponds with the GKC hypothesis $(+,-,+)$ of an S-shaped relationship between economic development and gender equality. Our statistical findings are consistent across all alternative measures of gender equality, giving us further confidence about the robustness of the GKC argument.

We performed additional robustness checks to increase confidence in our findings. Specifically, we estimated a generalized additive model (GAM) with a nonparametric regression spline to assess the hypothesized nonlinearity in per capita GDP. ${ }^{71}$ The results of the GAM model provide additional support for our contention that economic development exhibits a nonmonotonic relationship with gender equality. Nevertheless,

\footnotetext{
${ }^{69}$ Results from both the transformed and nontransformed models, as well as other alternative estimations, using imputed and nonimputed data are available in our online appendix; Eastin and Prakash 2012.

${ }^{70}$ Although we experimented with independent variable lags, human capital development arguably affects economic growth, which can create an endogeneity problem. Theoretically, an endogenous relationship should depict a monotonic relationship between human capital development and economic development. However, in the second stage of our analysis, we do not find that declines in gender norms have concomitant effects on growth. Though there may be some reciprocity in the first and third stages, we are confident that an endogenous relationship is not driving the full range our analysis.

${ }^{71}$ For further information on generalized additive models, see Wood 2000; and Wood 2004.
} 

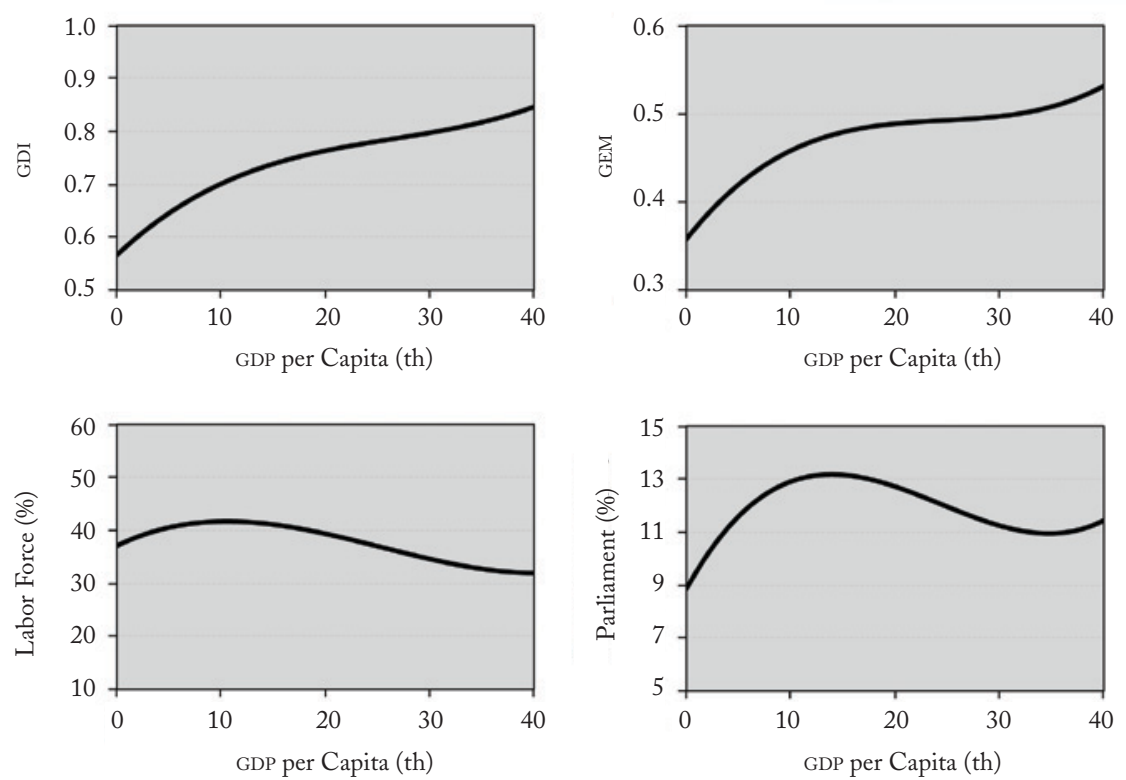

FIGURE 1

Gender Equality and Economic Growth

the statistics and graphs we present indicate that the polynomial modela linear mixed-effects model-provides a much better fit for the data. We compare the models in two key ways. First, we graph the actual versus the fitted values of both models on the full data set. These displays provide strong visual evidence that the polynomial mixed-effects model provides a better fit for the data than the GAM. Comparisons of each model's Bayesian information criterion (BIC) support this contention, as each of the polynomial model's BIC statistics is lower to a highly statistically significant degree $(\mathrm{p}<=.0001) .{ }^{72}$

Second, we perform a twofold out-of-sample cross-validation technique on both models to assess how each model's results generalize to an independent data set. ${ }^{73}$ Out-of-sample cross-validation procedures protect against errors associated with confirming hypotheses suggested by the data, because they use only the data that suggested these hypotheses in the first place. For this technique, we randomly divide the full data set into two subsets of equal size: a training set and a test set. We first estimate the models using the training set and then assess them on

\footnotetext{
${ }^{72}$ For information on the BIC, see Schwartz 1978; and Raftery 1995.

${ }^{73}$ For further information on cross-validation, see Fox 1997; and Ward, Greenhill, and Bakke 2010.
} 
TABLe 2

Linear Mixed Effects Models

\begin{tabular}{|c|c|c|c|c|}
\hline & $\begin{array}{c}\text { Gender } \\
\text { Development } \\
\text { Index } \\
\text { (Model 1) }\end{array}$ & $\begin{array}{l}\text { Gender } \\
\text { Equality } \\
\text { Measure } \\
\text { (Model 2) }\end{array}$ & $\begin{array}{c}\text { Female } \\
\text { Labor-Force } \\
\text { Participation } \\
\text { (Model 3) }\end{array}$ & $\begin{array}{c}\text { Female } \\
\text { Parliamentary } \\
\text { Participation } \\
\text { (Model 4) }\end{array}$ \\
\hline Intercept & $\begin{array}{l}0.514^{* * * *} \\
(0.012)\end{array}$ & $\begin{array}{l}0.340^{* * * *} \\
(0.009)\end{array}$ & $\begin{array}{c}37.776^{\text {**** }} \\
0.798\end{array}$ & $\begin{array}{l}7.121^{* * * *} \\
0.622\end{array}$ \\
\hline Per Capita GDP & $\begin{array}{l}1.855^{\text {**** }} \\
(0.250)\end{array}$ & $\begin{array}{l}1.514^{* * * *} \\
(0.220)\end{array}$ & $\begin{array}{l}95.903^{* * * *} \\
10.151\end{array}$ & $\begin{array}{l}71.745^{\text {**** }} \\
17.225\end{array}$ \\
\hline Per Capita GDP 2 & $\begin{array}{c}-0.058^{* *} \\
(0.019)\end{array}$ & $\begin{array}{c}-0.059^{* * * *} \\
(0.016)\end{array}$ & $\begin{array}{c}-5.728^{* * * *} \\
0.750\end{array}$ & $\begin{array}{c}-3.603^{* *} \\
1.293\end{array}$ \\
\hline Per Capita GDP 3 & $\begin{array}{c}0.007^{*} \\
(0.003)\end{array}$ & $\begin{array}{c}0.008^{* *} \\
(0.003)\end{array}$ & $\begin{array}{l}0.752^{\text {**** }} \\
0.125\end{array}$ & $\begin{array}{l}0.493^{*} \\
0.216\end{array}$ \\
\hline SAP & $\begin{array}{l}-0.008^{\text {**** }} \\
(0.002)\end{array}$ & $\begin{array}{l}-0.007^{* * *} \\
(0.002)\end{array}$ & $\begin{array}{l}0.217^{*} \\
0.084\end{array}$ & $\begin{array}{l}0.161 \\
0.154\end{array}$ \\
\hline Democracy & $\begin{array}{l}0.172^{* * *} \\
(0.022)\end{array}$ & $\begin{array}{l}0.130^{* * * *} \\
(0.020)\end{array}$ & $\begin{array}{l}4.682^{\text {**** }} \\
0.863\end{array}$ & $\begin{array}{l}6.773^{\text {**** }} \\
1.559\end{array}$ \\
\hline Conflict & $\begin{array}{c}-0.008^{*} \\
(0.003)\end{array}$ & $\begin{array}{c}-0.011^{* * * *} \\
(0.003)\end{array}$ & $\begin{array}{l}0.058 \\
0.122\end{array}$ & $\begin{array}{c}-1.498^{\text {**** }} \\
0.222\end{array}$ \\
\hline Exports & $\begin{array}{l}0.072^{\text {**** }} \\
(0.010)\end{array}$ & $\begin{array}{l}0.072^{* * * *} \\
(0.009)\end{array}$ & $\begin{array}{l}1.192^{\text {** }} \\
0.387\end{array}$ & $\begin{array}{l}2.435^{\text {**** }} \\
0.692\end{array}$ \\
\hline FDI & $\begin{array}{l}0.024^{\text {**** }} \\
(0.002)\end{array}$ & $\begin{array}{l}0.019^{* * * *} \\
(0.001)\end{array}$ & $\begin{array}{l}0.181^{\text {** }} \\
0.062\end{array}$ & $\begin{array}{l}1.374^{\text {**** }} \\
0.112\end{array}$ \\
\hline Industry & $\begin{array}{l}0.064^{* * * *} \\
(0.015)\end{array}$ & $\begin{array}{c}-0.034^{* *} \\
(0.014)\end{array}$ & $\begin{array}{c}-4.444^{* * * *} \\
0.599\end{array}$ & $\begin{array}{l}1.194 \\
1.073\end{array}$ \\
\hline GDP Growth & $\begin{array}{l}0.069^{* * * *} \\
(0.012)\end{array}$ & $\begin{array}{c}-0.024^{*} \\
(0.011)\end{array}$ & $\begin{array}{l}1.328^{* *} \\
0.473\end{array}$ & $\begin{array}{r}-0.982 \\
0.863\end{array}$ \\
\hline
\end{tabular}

3593 observations

${ }^{* * *} \mathrm{p}>.001,{ }^{* *} \mathrm{p}>.01,{ }^{*} \mathrm{p}>.05$; figures in parentheses are robust standard errors

the test set to measure model fit on independent data. We then repeat the procedure by reversing the roles of the two sets. Visual comparisons between the fit of polynomial model data on the full data set and on the out-of-sample data set in Figures 2-5 indicate that the polynomial models provide an excellent fit and possess striking predictive accuracy. Similarly, comparisons between the polynomial and spline models illustrate visually the superiority of the former over the latter. Finally, the polynomial model is simpler and more parsimonious than the spline model, which makes it more useful for substantive interpretation. 
Linear Mixed Effects Model (with polynomials)
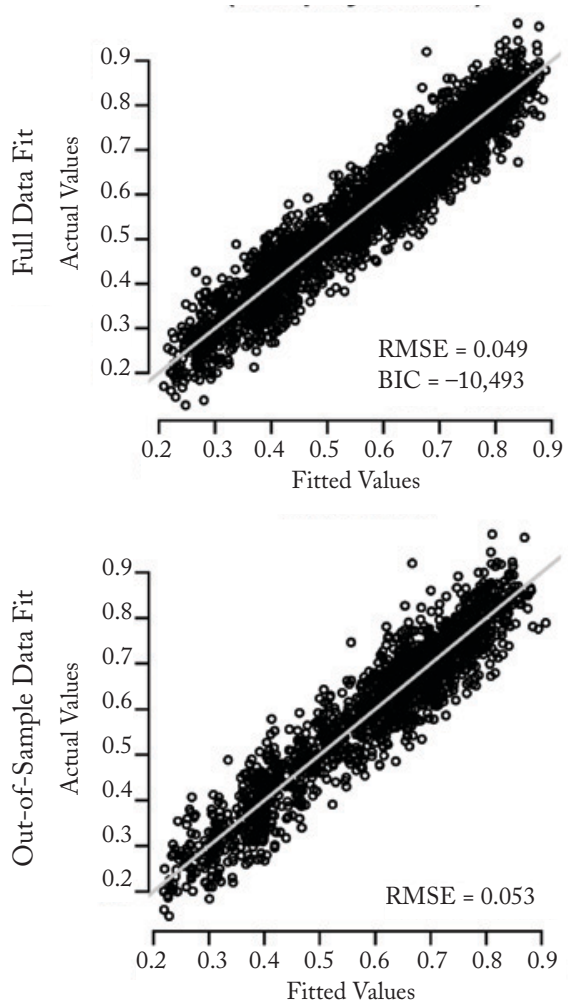

Generalized Additive Model (with spline)
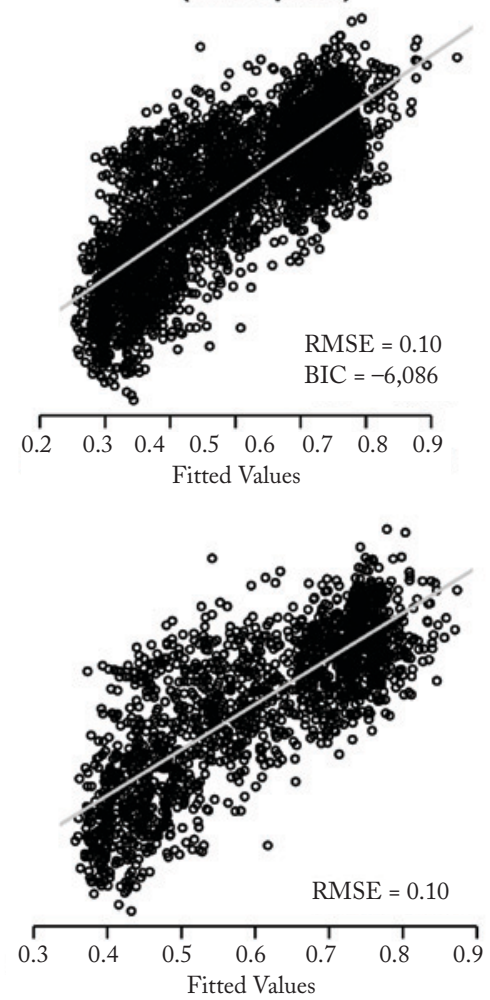

FiguRE 2

Gender Development Index Model Fits ${ }^{a}$

\footnotetext{
${ }^{\mathrm{a}} \mathrm{RMSE}$ is root mean square error.
}

Turning to the effects of the control variables on gender equality, we find contradictory evidence regarding the effects of SAPs on gender equality. This variable is significant and negatively associated with the gender indices in models 1 and 2 but significant and positively associated with Labor in model 3. Because the first two variables are indices, it is difficult to interpret what specific aspect of gender equality is negatively associated with SAP adoption. The positively signed and highly significant coefficient of SAPs in model 3 suggests that a reduction in governmental expenditures, often in social programs, necessitates a greater need for women to earn income outside the home. Democracy is positive and significant across all models, confirming the voluminous findings in earlier work. Conflict exhibits a strong negative relationship 
Linear Mixed Effects Model (with polynomials)

$\circ$

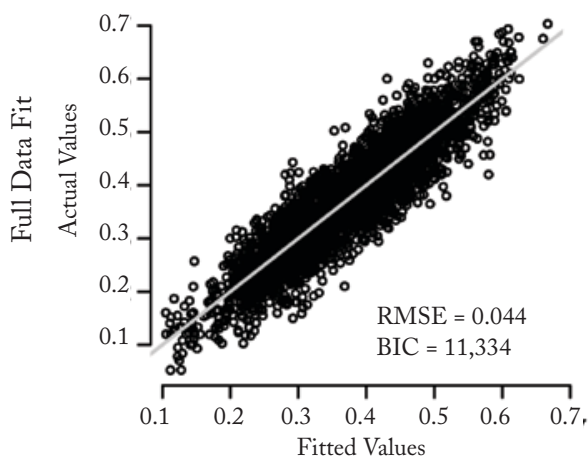

○

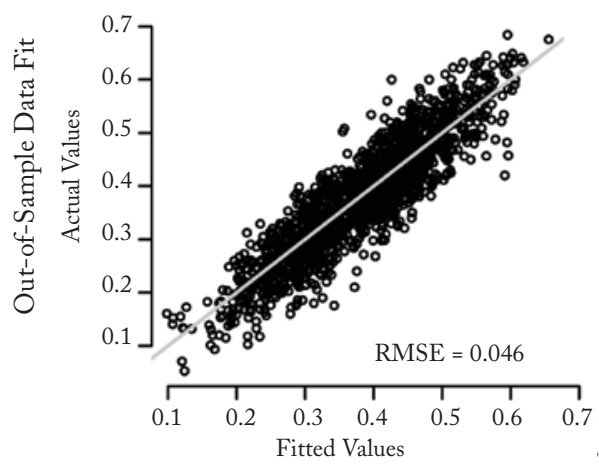

Generalized Additive Model (with spline)

○

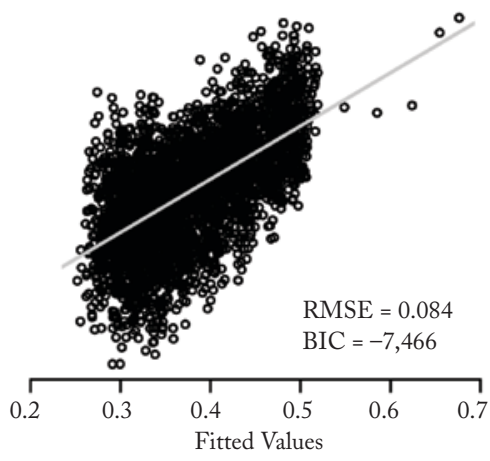

○

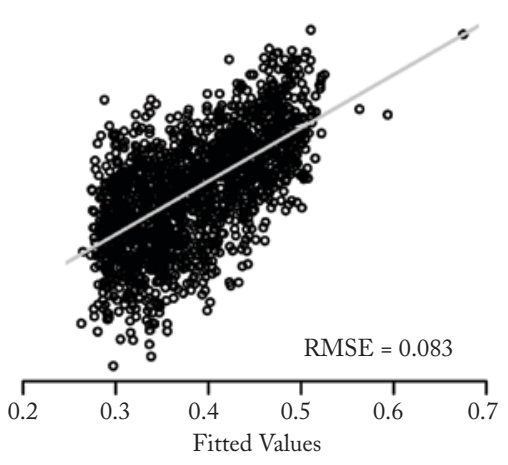

FiguRe 3

Gender Equality Measure Model Fits ${ }^{a}$

${ }^{a}$ RMSE is root mean square error.

with gender equality in all except model 3 (Labor). This relationship also confirms earlier work that suggests conflict is highly detrimental to gender equality. Indicators of economic globalization, Exports and FDI, have highly significant and positive effects on gender equality in all models. These results are consistent with prior studies that report a significant and positive impact of economic globalization on gender equality. ${ }^{74}$ Surprisingly, however, the Industry variable, which measures the salience of the manufacturing sector in the economy, has strong and negative effects in model 3 (Labor). Arguably, this finding can

${ }^{74}$ Richards and Gelleny 2007. 


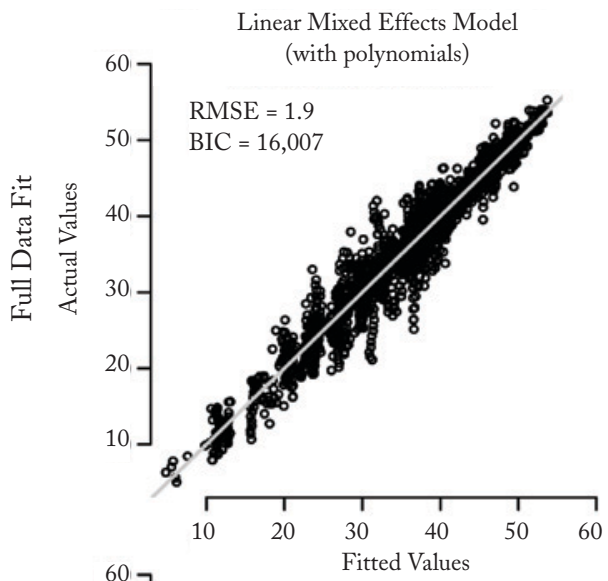

Generalized Additive Model (with spline)
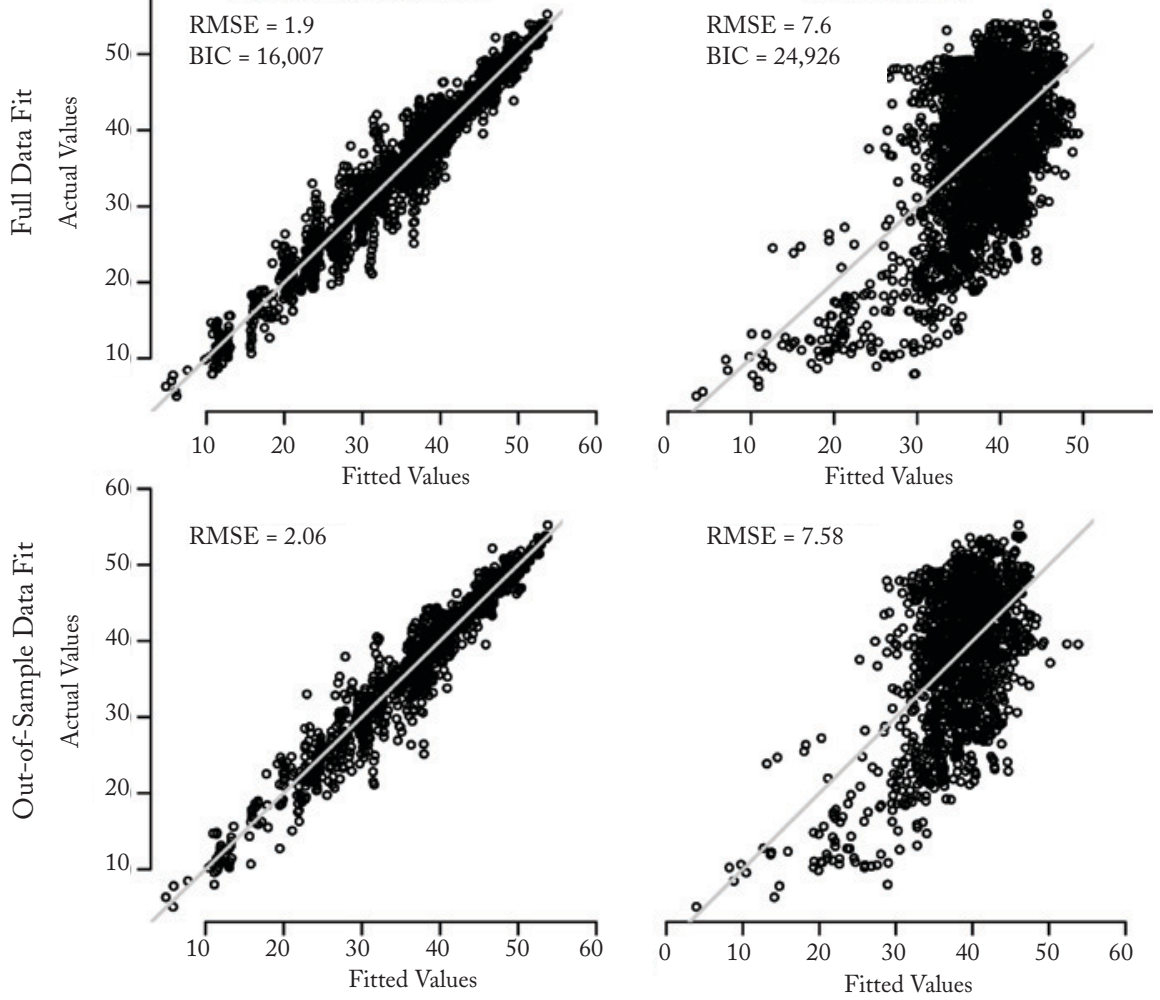

FIGURE 4

Female Labor Force Participation Model Fits ${ }^{a}$

${ }^{a} \mathrm{RMSE}$ is root mean square error.

reflect the impact that industry has on labor-force stratification, or it may indicate that women are simply required to stay at home while men work in the formal labor force (the income effect outweighing the substitution effect, as Goldin suggests). While Growth appears to significantly influence gender equality, the directionality is unclear. Growth has a positive effect on GDI and Labor, and a negative effect on GEM. This suggests that while growth can increase female labor-force participation by providing more jobs overall, the types of jobs that growth provides might reinforce gender segregation and subordination that can adversely affect equality gains. 


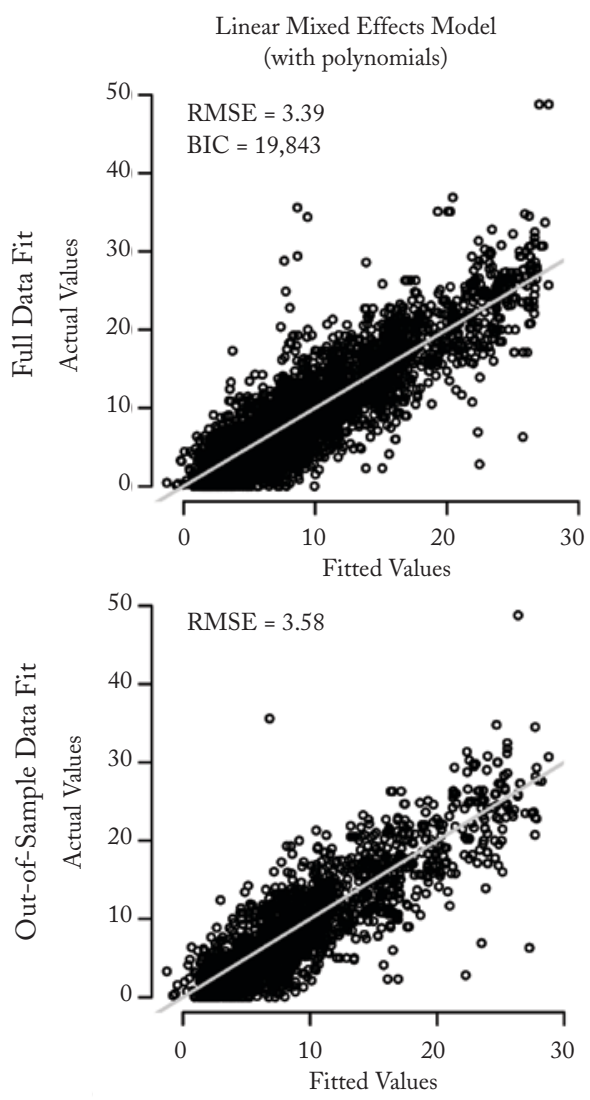

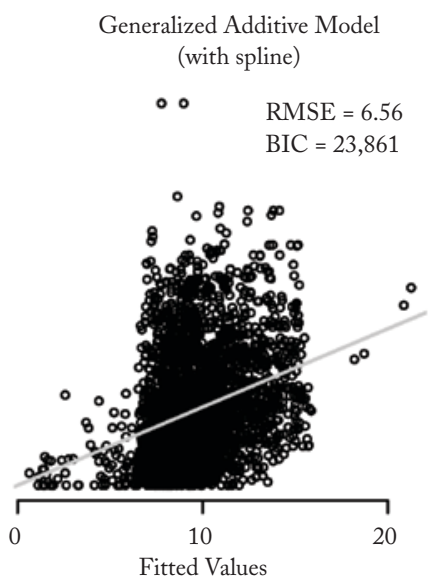

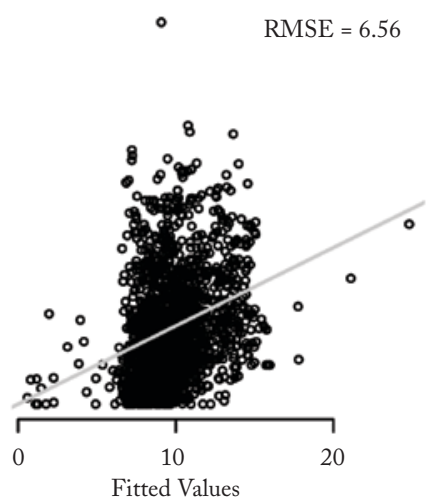

FiguRe 5

Female Parliamentary Participation Model Fits ${ }^{a}$

${ }^{\mathrm{a}} \mathrm{RMSE}$ is root mean square error.

\section{Conclusions}

Simon Kuznets's insight that the effect of economic development on income inequality is contingent on the levels of development travels well to the context of gender equality. We present evidence to suggest economic development and gender equality have a curvilinear relationship - a discernible S-shaped gender Kuznets curve. This challenges both the feminist and the neoclassical perspectives, both of which identify the effects of development on gender equality as monotonic or unidirectional. It builds on and develops prior work that reports a U-shaped relationship. It is our hope that this article will motivate policy action, especially in the second phase. The inflexion points we 
report are not magic thresholds. Our story is about economic development interacting with social institutions to alter fundamental political relationships between genders. While the estimated inflexion points reflect the experience of 146 countries for the period 1980-2005, we hope that new technologies, norms, and social action will shift inflexion points in ways that will shrink the second phase.

Any kind of inequality reflects power asymmetry. Over time, such inequality gets concretized into social norms. Any force that seeks to alter these norms confronts the status quo- the patriarchal institutions and their beneficiaries discussed in our narrative. Economic growth is disruptive because it affords women an independent income stream, provides them with social and economic visibility, and allows them to accumulate human capital. Eventually, it creates a demand for change. However, change is not always forthcoming, as the second stage illustrates, because status quo beneficiaries seek to reverse equality gains. This pushback often manifests itself as a call to return to "traditional values." The changing opportunity cost of women not joining the labor force also affects the balance of power between progressive and reactionary forces. Thus, we have outlined a political story of change that to a great extent is rooted in structural changes in the economy, the opportunities for women to participate in the labor force, and the emergence of women as actors with independent income streams.

Five important issues emerge for future research. First, this article has presented a macrostory about the relationship between gender equality and economic development. In particular, we have identified several mechanisms that lead to equality blowback in the second stage. These include cultural, economic, and social factors rooted in lower opportunity costs of female labor-force withdrawal and the rearticulating of regressive social norms. Arguably, the blowback might also reflect a more general phenomenon of opposition to Western norms, including gender norms. Future microlevel studies should assess the salience of different mechanisms in initiating and sustaining the blowback because these mechanisms could vary across political, social, and economic contexts.

Second, our work contributes to the broader literature that examines nonmonotonic relationship between development and sociopolitical variables such as Przeworksi et al.'s work on the relationship between income and political transitions. We hope our work will motivate scholars to examine how economic development might shape other types of sociopolitical variables ranging from policies toward different types of minority groups to public health issues. 
Third, scholars should explore whether different sources of growth have varying consequences for gender equality. Would, for example, economic growth rooted primarily in the exploitation of natural resources have the same consequences for gender equality as economic growth based on human capital-based industrialization? Different paths to economic development may empower different sectors of society that hold varying preferences for gender equality. This might have significant consequences for the economic, political, and social structures that influence gender equality. Arguably, some developmental paths strengthen patriarchal structures and discourage women from investing in human capital, eventually undermining gender equality. Thus, before advocating the view that "globalization and economic growth is the panacea for all ills," free-market advocates should think carefully about the consequences of different growth processes for social issues and for gender equality in particular.

Indeed, in recent years, intergovernmental organizations such as the United Nations and the World Bank have argued for direct interventions to create the market and other social institutions necessary for gender and social equality. These institutions have directed their efforts toward reducing structural disparities that hinder women's access to and participation in formal labor markets, such as education and workforce training, increased credit access for female-owned businesses, provision of low-cost renewable energy technology, and promotion of female agricultural cooperatives. The Millennium Development Goals also emphasize women's economic empowerment. ${ }^{75}$ It remains to be seen how effective such interventions are at creating new opportunities for women.

Fourth, the subject of income thresholds or inflexion points needs to be explored further. Based on our data, we estimated two income thresholds (\$8,000-10,000 and $\$ 25,000-30,000)$ for the curvilinear relationship between development and gender equality. As the literature critiquing "stages of economic growth" suggests, the movement from one stage to another stage should not be viewed as automatic or a oneway process. Indeed, the social, political, and economic institutional arrangements in which the development process unfolds can influence these thresholds. Arguably, policy interventions (which may be motivated by growth beneficiaries) can modify and change some of these arrangements. Institutional change upsets the status quo and is often contested. ${ }^{76}$

\footnotetext{
${ }^{75}$ World Bank 2006.

${ }^{76}$ North 1990.
} 
How might one proceed to alter these threshold levels? Some might perceive policy measures to enhance gender equality as undermining other social goals. Take the Indian case as an illustrative example. ${ }^{77}$ For the last several years, the Indian Parliament has been unable to pass the 108th Amendment Bill that mandates a 33 percent reservation for women in all legislative bodies. ${ }^{78}$ While the major national partiesthe Congress, the BJP, and the Communists-support this bill, it is being vehemently opposed by parties that claim to represent the interest of some minority groups and the so-called backward and lower castes (such as the Lalu Yadav's Rashtriya Janata Dal, Mulayam Singh Yadav's Samajwadi Party, and Ram Bilas Paswan's Lok Janshakti Party). These opposing groups suggest that by virtue of the higher educational levels and economic status of upper-caste, urban, westernized women (who are typically not their constituency), the latter will be the major beneficiaries of this bill. ${ }^{79}$ The opposing groups, that is, do not view "women" as an undifferentiated category and therefore demand "reservations within reservations" for women belonging to the backward and lower castes (SC, scheduled castes; ST, scheduled tribes; and the Mandal castes). For them, caste trumps gender. The lesson is that in societies marked by multiple, nonoverlapping social cleavages, equality in one sphere might be perceived as undermining equality in other spheres. Future research needs to carefully examine the politics of focusing on specific development strategies as well policy interventions to change inequitable social arrangements. Indeed, if the Indian Parliament does succeed in passing this bill, it would be instructive to study its subsequent effects on gender equality.

Finally, how norm-based globalization might affect the income thresholds as well as gender equality in specific development phases requires careful examination. While scholars tend to emphasize the diffusion of secular and liberal norms, the information revolution and the rise of the civil society has facilitated the diffusion of all types of norms, including fundamentalist norms. In several countries there is a resurgence of "bad civil society" that challenge notions of gender equality. With competing norms, ${ }^{81}$ it

\footnotetext{
${ }^{77}$ Hasan, Sridharan, and Sudarshan 2005.

${ }^{78}$ Women's Reservation Bill possible only after 2009 polls.

${ }^{79}$ The language used in some parliamentary debates shows the attitudes toward gender issues. A prominent leader argued that gender quotas are a power grab by urban, educated women - described as the types who had cut their hair (baal kati). The term, which translates as women who have cut their hair, is a derogatory term for urban, educated, westernized women.

${ }^{80}$ Chambers and Kopstein 2001.

${ }^{81}$ Sell and Prakash 2004.
} 
is not clear which ones will prevail, why, and with what consequences for gender equality. This is an important issue for future research.

\section{REFERENCES}

Abouharb, M. Rodwan, and David Cingranelli. 2006. "The Human Rights Effects of World Bank Structural Adjustment Lending, 1981-2000.” International Studies Quarterly 50, no. 2: 233-62.

Acker, Joan. 2004. "Gender, Capitalism and Globalization." Critical Sociology 30, no. 1: 24-46.

Apodaca, Claire. 2001. "Global Economic Patterns and Personal Integrity Rights after the Cold War." International Studies Quarterly 45, no. 4: 587-602.

Balabanova, Evgeniia Sergeevna. 2007. "Women's Economic Dependency." Sociological Research 46, no. 2: 5-21.

Becker, Gary S. 1985. "Human Capital, Effort, and the Sexual Division of Labor." Journal of Labor Economics 3, no. 1: 33-58.

Beneria, Lourdes, and Gita Sen. 1982. "Class and Gender Inequalities and Women's Role in Economic Development: Theoretical and Practical Implications." Feminist Studies 8, no. 1: 157-76.

Bergeron, Suzanne. 2001. "Political Economy Discourses of Globalization and Feminist Politics.” Signs 26, no. 4: 983-1006.

Blackburn, Robert M., and Jennifer Jarman. 2006. "Gendered Occupations: Exploring the Relationship between Gender Segregation and Inequality." International Sociology 21, no. 2: 289-315.

Blaydes, Lisa, and Drew A. Linzer. 2008. "The Political Economy of Women's Support for Fundamentalist Islam.” World Politics 60, no. 4 (July): 576-609.

Boserup, Ester. 1970. Women's Role in Economic Development. New York, N.Y.: St. Martin's.

Cao, Xun, Brian Greenhill, and Aseem Prakash. Forthcoming. "Where Is the Tipping Point? Bilateral Trade and the Diffusion of Human Rights, 19822004." British Journal of Political Science.

Cao, Xun, and Aseem Prakash. 2010. "Trade Competition and Domestic Pollution: A Panel Study, 1980-2003." International Organization 64, no. 3: 481503.

Chambers, Simone, and Jeffrey Kopstein. 2001. "Bad Civil Society." Political Theory 29, no. 6: 837-65.

Charmes, Jacques, and Saskia Wieringa. 2003. "Measuring Women's Empowerment: An Assessment of the Gender-Related Development Index and the Gender Empowerment Measure." Journal of Human Development 4, no. 3: 419-35.

Clark, Roger. 1991. “Contrasting Perspectives on Women's Access to Prestigious Occupations: A Cross-National Investigation." Social Science Quarterly 72, no. 1: 20-32.

Clark, Roger, Thomas W. Ramsbey, and Emily Steir Adler. 1991. "Culture, Gender, and Labor Force Participation: A Cross-National Study." Gender and Society 5, no. 1: 47-66.

DasGupta, Monica. 1987. "Selective Discrimination against Female Children in Rural Punjab, India." Population and Development Review 13, no 1: 77-99. 
Deere, Carmen Dianna. 2005. "The Feminization of Agriculture: Economic Restructuring in Latin America.” Occasional Paper 1. Research Institute for Social Development: United Nations.

Dollar, David, and Roberta Gatti. 1999. "Gender Inequality, Income, and Growth: Are Good Times Good for Women?" Gender and Development Working Paper Series no. 1. Washington, D.C.: World Bank.

Douthat, Ross. 2011. "160 million and Counting." New York Times. June 27. At http://www.nytimes.com/2011/06/27/opinion/27douthat.html?_r=3\&ref= rossdouthat, accessed February 27, 2012.

Draper, Elaine. 1985. "Women's Work and Development in Latin America." Studies in Comparative International Development 20, no. 1:3-30.

Eastin, Joshua, and Aseem Prakash. 2012. Online Appendix. At http://faculty .washington.edu/aseem/Articles.html.

Economist. 2011. "Add Sugar and Spice: India's Sex Ratio Is Getting Worse.” At http://www.economist.com/node/18530101/comments?page=1, accessed October 4, 2011.

Folbre, Nancy. 1986. "Cleaning House: New Perspectives on Households and Economic Development.” Journal of Development Economics 22, no. 2: 5-40.

Forsythe, Nancy, Roberto Patricio Korzeniewicz, and Valerie Durrant. 2000. "Gender Inequalities and Economic Growth: A Longitudinal Evaluation." Economic Development and Cultural Change 48, no. 3: 573-617.

Fox, Jon. 1997. Applied Regression Analysis, Linear Models, and Related Methods. Thousand Oaks, Calif.: Sage Press: 514-18.

Gangoli, Geetanjali. 2006. "Engendering Genocide: Gender, Conflict and Violence." Women's Studies International Forum 29, no. 5: 534.

Gleditsch, Nils Petter, Peter Wallensteen, Mikael Eriksson, Margareta Sollenberg, and Havard Strand. 2002. "Armed Conflict 1946-2001: A New Dataset." Journal of Peace Research 39, no. 5: 621-32.

Goldin, Claudia. 1990. Understanding the Gender Gap: An Economic History of American Women. New York, N.Y.: Oxford University Press.

—. 1995. "The U-Shaped Female Labor Force Function in Economic Development and Economic History." In T. P. Schultz, ed., Investment in Women's Human Capital and Economic Development. Chicago, Ill.: University of Chicago Press.

Gray, Mark M., Miki Caul Kittilson, and Wayne Sandholtz. 2006. "Women and Globalization: A Study of 180 Countries, 1975-2000." International Organization 60, no. 2: 293-333.

Grossman, Gene, and Alan Krueger. 1995. "Economic Growth and the Environment." Quarterly Journal of Economics 110, no. 2: 353-77.

Hancock, Peter J. 2006. "Women, Work and Empowerment: A Portrait of Women Workers in Two of Sri Lanka's Export Processing Zones." Norwegian Journal of Geography 60, no. 3: 227-39.

Harbom, Lotta. 2007. UCDP/PRIO Armed Conflict Data Codebook, version 4. Uppsala, Sweden: Uppsala Conflict Data Program and International Peace Research Institute: 4.

Hasan, Zoya, Eswaran Sridharan, and R. Sudarshan. 2005. India's Living Constitution: Ideas, Practices, Controversies. London, UK: Anthem Press.

Hemmati, Minu. 2001. "Gender-Specific Patterns of Poverty and (Over)Consumption in Developing Countries." In Eberhard Sathaye, Jayant A. 
Sathaye, and Daniel Biulle, eds., Society, Behavior, and Climate Change Mitigation. London, UK: Klewer Publications

Hvistendahl, Mara, 2011. Unnatural Selection: Choosing Boys over Girls and the Consequences of a World Full of Men. New York, N.Y.: Public Affairs.

IMF Emerging and Developing Economies List. 2008. World Economic Outlook Database, April 2008. At http://www.imf.org/external/pubs/ft/weo/2008/01/ weodata/index.aspx, accessed July 27, 2008.

Inglehart, Ronald. 1977. The Silent Revolution: Changing Values and Political Styles among Western Publics. Princeton, N.J.: Princeton University Press.

-1997. Modernization and Post-modernization: Cultural, Economic, and Political Change in 43 Societies. Princeton, N.J.: Princeton University Press.

Inkles, Alex, and David H. Smith. 1974. Becoming Modern. Cambridge, Mass.: Harvard University Press.

Iversen, Torbin, and Frances Rosenbluth. 2005. "Gender Socialization: How Bargaining Power Shapes Social Norms and Political Attitudes." Working Paper, no. 2008-0064. Cambridge, Mass.: Weatherhead Center for International Affairs, Harvard University.

- 2006. "The Political Economy of Gender: Explaining Cross-National Variation in the Gender Division of Labor and the Gender Voting Gap." American Journal of Political Science 50, no. 1: 1-19.

Jansen, Golie G. 2006. "Gender and War: The Effects of Armed Conflict on Women's Health and Mental Health." Journal of Women and Social Work 21, no. 2: 124-45.

Jütting, Johannes P., Christian Morrisson, Jeff Dayton-Johnson, and Denis Drechsler. 2006. "Measuring Gender (In)Equality: Introducing the Gender, Institutions and Development Data Base (GID)." Journal of Human Development 9, no. 1: 65-86.

Kanbur, Ravi, and Michael Spence, eds. 2010. Equity and Growth in a Globalizing World. Washington, D.C.: World Bank.

Kuznets, Simon. 1955. "Economic Growth and Income Inequality." American Economic Review 45, no. 1: 1-28.

Lantican, Clarita P., Christina H. Gladwin, and James L. Seale Jr. 1996. "Income and Gender Inequalities in Asia: Testing Alternative Theories of Development." Economic Development and Cultural Change 44, no. 2: 235-63.

Marshall, Monty G., and Keith Jaggers. 2005. Polity IV Project: Political Regime Characteristics and Transitions, 1800-2003. At http//:www.cidm.umd.edu/incr/ polity, accessed June 19, 2008.

Measuring Inequality: Gender-Related Development Index (GDI) and Gender Empowerment Measure (GEM). 1995. At http://hdr.undp.org/en/statistics/ indices/gdi_gem/, accessed July 29, 2008.

Mincer, Jacob. 1958. "Investment in Human Capital and Personal Income Distribution." Journal of Political Economy 66, no. 4: 281-302.

Mummert, Gail. 1994. "From Metate to Despate: Rural Mexican Women's Salaried Labour and the Redefinition of Gendered Spaces and Roles.” In Heather Fowler-Salamini and Mary Kay Vaughan, eds., Women of the Mexican Countryside, 1850-1990. Tucson, Ariz.: University of Arizona Press.

newKerala.com. 2009. "Women's Reservation Bill Possible Only after 2009 Polls." 
At http://www.newkerala.com/topstory-fullnews-21249.html, accessed June 23, 2011.

North, Douglas. 1990. Institutions, Institutional Change, and Economic Performance. New York, N.Y.: Cambridge University Press.

Oppenheimer, Valerie K. 1970. The Female Labor Force in the United States: Demographic and Economic Factors Governing Its Growth and Changing Composition. Berkeley, Calif.: Institute of International Studies, University of California Press.

Przeworski, Adam, Michael Alvarez, Jose Antonio Cheibub, and Fernando Limongi. 2000. Democracy and Development: Political Institutions and Well-Being in the World, 1950-1990. Cambridge, UK: Cambridge University Press.

Raftery, Adrian. 1995. "Bayesian Model Selection in Social Science Research." Sociological Methodology 25: 111-63.

Rao, Aruna, and David Kelleher. 2005. "Is There Life after Gender Mainstreaming?" Gender and Development 13, no. 2: 57-69.

Richards, David L., Ronald D. Gelleny, and David H. Sacko. 2001 "Money with a Mean Streak? Foreign Economic Penetration and Government Respect for Human Rights in Developing Countries." International Studies Quarterly 45, no. 2: 219-39.

Richards, David L., and Ronald Gelleny. 2007. "Women's Status and Economic Globalization.” International Studies Quarterly 51, no. 4: 855-76.

Ross, Michael 2008. "Oil, Islam, and Women." American Political Science Review 102, no. 2: 107-23.

Saffioti, Helieth. 1978. Women in Class Society. New York, N.Y.: Monthly Review Press.

Sarasúa, Carmen. 2008. "Technical Innovations at the Service of Cheaper Labor in Pre-Industrial Europe: The Enlightened Agenda to Transform the Gender Division of Labor in Silk Manufacturing." History and Technology 24, no. 1: 23-39.

Schwartz, Gideon. 1978. "Estimating the Dimension of a Model." Annals of Statistics 6, no. 2: 461-64.

Seguino, Stephanie. 2007. "Plus Ça Change? Evidence on Global Trends in Gender Norms and Stereotypes." Feminist Economics 13, no. 2: 1-28.

Sell, Susan, and Aseem Prakash. 2004. "Using Ideas Strategically: Examining the Contest between Business and NGO Networks in Intellectual Property Rights.” International Studies Quarterly 48, no. 1: 143-75.

Siddhanta, Suddhasil, Debasish Nandy, and Satish B. 2005. "Agnihotri Sex Ratios in India and the Prosperity Effect." At http://iussp2005.princeton.edu/download.aspx?submissionId=52129, accessed November 15, 2011.

Spierings, Niels, Jeroen Smits, and Mieke Verloo. 2009. "On the Compatibility of Islam and Gender Equality.” Social Indicators Research 90, no. 3: 503-22.

Steel, Gill, and Ikuo Kabashima. 2008. "Cross-Regional Support for Gender Equality." International Political Science Review 29, no. 2: 133-56.

Sudarkasa, Niara. 1986. "The Status of Women in Indigenous African Societies." Feminist Studies 12, no. 1: 91-103.

Tinker, Irene. 1976. “The Adverse Impact of Development on Women.” In Irene Tinker and Michele Bo Bramsen, eds., Women and World Development. Washington, D.C.: Overseas Development Council. 
Tinker, Irene, and Michele Bo Bramsen. 1976. Women and World Development. Washington, D.C.: Overseas Development Council.

United Nations Conference on Trade and Development: Foreign Direct Investment Database. At http://www.unctad.org/Templates/Page.asp?intItemID=1923, accessed May 9, 2008.

United Nations Development Program. 1999. Human Development Report. New York, N.Y.: United Nations.

United Nations: Gender Equality Measure. At http://hdr.undp.org/en/statistics/ indices/gdi_gem/, accessed June 23, 2008.

United Nations: Gender-related Development Index. At http://hdrstats.undp .org/indicators/269.html, accessed June 23, 2008.

United Nation Human Development Report. 1995. Gender and Human Development. New York, N.Y.: United Nations.

United Nations Research Institute for Social Development. 2005. "Gender Equality: Striving for Justice in an Unequal World." Policy Report on Gender and Development: 10 Years after Beijing. New York, N.Y.: United Nations.

United Nations Entity for Gender Equality and the Empowerment of Women. 2011. At http://www.un.org/womenwatch/osagi/conceptsandefinitions.htm, accessed November 11, 2011.

Ward, Kathryn. 1984. Women in the World System: Its Impact on Status and Fertility. New York, N.Y.: Praeger.

Ward, Michael D., Brian D. Greenhill, and Kristin M Bakke. 2010. "The Perils of Policy by p-Value: Predicting Civil Conflicts" Journal of Peace Research 47, no. 4: 363-75.

Weiss, Jane A., Fransisco O. Ramirez, and Terry Tracy. 1976. "Female Participation in the Occupational System: A Comparative Institutional Analysis." Social Problems 23, no. 5: 525-34.

Wilensky, Harold L. 1968. "Women's Work: Economic Growth, Ideology, and Social Structure." Industrial Relations 7, no. 3: 235-48.

Wood, Simon N. 2000. "Modeling and Smoothing Parameter Estimation with Multiple Quadratic Penalties." Journal of the Royal Statistical Society 62, Series B: 413-28.

_ 2004. "Stable and Efficient Multiple Smoothing Parameter Estimation for Generalized Additive Models." Journal of the American Statistical Association 99, no. 467: 673-86.

World Bank. 2006. Gender Equality as Smart Economics: A World Bank Group Gender Action Plan. At http://siteresources.worldbank.org/INTGENDER/ Resources/GAPNov2.pdf, accessed November 11, 2011.

Youssef, Nadia H. 1972. "Differential Labor Force Participation of Women in Latin America and Middle Eastern Countries: The Influence of Family Characteristics." Social Forces 51, no. 2: 135-53.

Zeng, Ka, and Joshua Eastin. 2011. Greening China: The Benefits of Trade and Foreign Direct Investment. Ann Arbor, Mich.: University of Michigan Press.

Zorn, Christopher J. W. 2001. "Generalized Estimating Equation Models for Correlated Data: A Review with Applications." American Journal of Political Science 45, no. 2: 470-90. 